\title{
Opiate-use patients attending residential treatment: characteristics, outcomes, and implications for practice
}

\author{
Samuel A MacMaster ${ }^{1}$, Siobhan A Morse ${ }^{2^{*}}$, Brian Bride ${ }^{3}$, John Seiters ${ }^{2}$, Cayce M Watson ${ }^{4}$, Sam Choi $^{1}$ \\ From 2014 Addiction Health Services Research (AHSR) Conference \\ Boston, MA, USA. 15-17 October 2014
}

\section{Background}

As opiate use has increased, there has been a corresponding increase in the number of opiate users presenting for treatment. Questions regarding the challenges of treating opiate users in residential treatment remain largely unanswered. This study seeks to determine what, if any, meaningful differences exist between opiate and non-opiate users, as well as within opiate users who enter voluntary, private, or residential dual-diagnosis treatment, and the impact of any differences relative to treatment motivation, length, and outcomes.

\section{Materials and methods}

Data for this study were drawn from 1972 individuals, utilizing the Addiction Severity Index, the Treatment Service Review, the University of Rhode Island Change Assessment, and a satisfaction measure. Interviews were conducted at program intake, and 1 and 6-month interviews post-discharge.

\section{Results}

The results suggest that although there are similarities there are also some important differences in characteristics, motivation, completion, engagement, retention, levels of satisfaction, and post-treatment service use. Additional analyses were conducted when significant within-group differences by age for opiate users were revealed.

\section{Conclusions}

Results suggest different strategies within treatment programs may provide benefit in targeting the disparate needs of younger opiate users. Outcome results at

\footnotetext{
* Correspondence: Siobhan.Morse@frnmail.com

${ }^{2}$ Foundations Recovery Network in Nashville, Brentwood, TN, 37027, USA

Full list of author information is available at the end of the article
}

6 months for all groups demonstrated significant improvement over pretreatment, suggesting that abstinence-based treatment can be an effective form of treatment for opiate users.

\section{Authors' details}

'College of Social Work, University of Tennessee, Nashville, TN, 37210, USA. ${ }^{2}$ Foundations Recovery Network in Nashville, Brentwood, TN, 37027, USA.

${ }^{3}$ School of Social Work, Georgia State University, Atlanta, GA, 30303, USA.

${ }^{4}$ School of Social Work, David Lipscomb University, Nashville, TN, 37204, USA.

Published: 20 February 2015

doi:10.1186/1940-0640-10-S1-A36

Cite this article as: MacMaster et al:: Opiate-use patients attending residential treatment: characteristics, outcomes, and implications for practice. Addiction Science \& Clinical Practice 2015 10(Suppl 1):A36.
Submit your next manuscript to BioMed Central and take full advantage of:

- Convenient online submission

- Thorough peer review

- No space constraints or color figure charges

- Immediate publication on acceptance

- Inclusion in PubMed, CAS, Scopus and Google Scholar

- Research which is freely available for redistribution

\section{() Biomed Central}

C Biomed Central

(c) 2015 MacMaster et al; licensee BioMed Central Ltd. This is an Open Access article distributed under the terms of the Creative Commons Attribution License (http://creativecommons.org/licenses/by/4.0), which permits unrestricted use, distribution, and reproduction in any medium, provided the original work is properly cited. The Creative Commons Public Domain Dedication waiver (http://creativecommons.org/publicdomain/zero/1.0/) applies to the data made available in this article, unless otherwise stated. 